\title{
International Business Accounting Standardization and Hungarian Practice
}

\author{
Jeno Beke \\ Institute of Business and Management, Faculty of Business and Economics \\ University of Pecs, Hungary (Europe) \\ Tel: 36-72-313-681Ｅ-mail: bekej@ktk.pte.hu
}

\begin{abstract}
The goal of this study is to describe and summarize the differences between national accounting rules and international standards, then the valuing and analyzing their effects on business decisions, management performance and economic environment in Hungary. Financial data are from published financial statements and Hungarian Business Information database. My sample comprises 65 international standards adopting and 260 local accounting rules user firms. This paper showed that both businesses earnings and stock returns effect on the management turnover. Businesses with lower labour productivity compared to their industry peers have greater incentives to adopt international accounting standards. Sensitivity of CEO turnover to accounting earnings increased after the adoption of international system. Businesses with higher leverage and lagged sales growth have more frequent employee layoffs. Standards user enterprises' employee layoffs are more response to accounting performance in the post-adoption period.
\end{abstract}

Keywords: Business accounting, Accounting standards, Standardization, Harmonization, Globalization, Economic effects, Hungary

\section{Introduction}

The goal of international business accounting is to provide a set of tools that can be used to meet the requirements of each application. Since accounting applications do not have uniform security and reliability requirements, it is not possible to devise a single accounting protocol and set of security services that will meet all needs. Business management requires that resource consumption be measured, rated, assigned, and communicated between appropriate parties. Managers of businesses use accounting information to set goals for their organizations, to evaluate their progress toward those goals, and to take corrective action if necessary. Decisions based on international business accounting system may include which building and equipment to purchase, how much merchandise inventory to keep on hand, and how much cash to borrow, etc. Modern business accounting renders its services to a wide variety of users: investors, government agencies, the public, and management of enterprises, to mention but a few. Many accountants work in business enterprises as managerial accountants, internal auditors, income tax specialists, systems experts, controllers, management consultants, financial vice presidents, and chief executives.

Business accounting is, therefore, a service to management, a special-purpose tool which must be used but not misused. Like any special-purpose tool, if it is neglected or not used it will surely go rusty and fail to provide the good service for which it was designed. However, all tools have their limitations and it is well to point out at this early stage some fundamental limitations inherent in any system of business accounting.

The importance of accounting within a business should not be underestimated. It provides the basic information by which managers and owners can judge whether the business is meeting its objectives. Its importance is shown by the high salaries that accountants can command and by the prevalence of accountants on the boards of directors of major public companies.

Accounting is also different from other business functions in that it is not only a function but also an industry. The accounting industry sells accounting and other advisory services to other businesses and is itself a major employer of graduate labour. Accounting can be and is used within business to evaluate and shape alternative strategies such as making a component of buying it in from a supplier, thus shaping business plans and activities. At the same time it is itself a function of the type of activity that a business engages in and of the strategies a business adopts.

Business accountants focus on the planning and controlling functions in an enterprise and prepare internal management reports and related analyzes to meet the needs of management. Accounting has often been called the "language of business". The underlying purpose of accounting is to provide financial information about an economic 
entity. The financial information provided by an accounting system is needed by business decision makers to help then plan and control the activities of the economic entity.

In this paper, the goal is to describe and summarize how the international accounting system can help business decisions and influence the business environment in a global scale. The unified, standardized accounting information system will lead to new types of analysis and data, furthermore with the possible integration of new indicators from the business practice of certain countries.

The purpose of the use of international accounting information system is that a single set of standards ensures similar transactions are treated the same by companies around the world, resulting in globally comparable financial statements. However, using the accounting standards consistently by firms we will find that they are changeable, because they are depend on the varying economic, political, and cultural conditions in one state. Accounting standard-setters and regulators around the globe are planning to harmonize accounting standards with the goal of creating one set of high-quality accounting rules to be applied around the world (Whittington, 2008).

The globalization of international financial markets has increased the need for world-wide comparable accounting standards and regulation. The required implementation of International Financial Reporting Standards (IFRS) by listed firms that operate in member-states of the European Union, as of January 1, 2005, should assist investors in their decision-making and enhance stock market efficiency. At the same time, the world-wide acceptance of IFRS may indicate their high-quality.

Globalization describes a process by which regional economies, societies, and cultures have become integrated through a global network of communication, transportation, and trade. The term is sometimes used to refer specifically to economic globalization. The integration of national economies into the international economy through trade, foreign direct investment, capital flows, migration, and the spread of technology.

With increasing globalization of the marketplace, international investors need access to financial information based on harmonized accounting standards and procedures. Investors constantly face economic choices that require a comparison of financial information. Without harmonization in the underlying methodology of financial reports, real economic differences cannot be separated from alternative accounting standards and procedures. Harmonization is used as a reconciliation of different points of view, which is more practical than uniformity, which may impose one country's accounting point of view on all others. Organizations, private or public, need information to coordinate its various investments in different sectors of the economy. With the growth of international business transactions by private and public entities, the need to coordinate different investment decisions has increased.

The transition to IFRS presents firms with difficulties including technical differences, the cost of change and adjustment, the time factor, and the insufficient experience and knowledge. In addition the fair value orientation of IFRS is likely to introduce volatility in book values and reported earnings, and consequently, distort the financial profile of adopting firms. These considerations may influence the financial behaviours of businesses and may motivate them to redefine their strategies and decision-making processes in order to mitigate the adverse impact of adoption on their accounting numbers.

Historically, standardization of the international accounting systems has tended to follow the integration of the markets served by the accounts. For example, the move to unified national accounting system in the US in the early $20^{\text {th }}$ century followed the integration of the national economy. Similarly the present impetus for global accounting standards follows the accelerating integration of the world economy. Without the common accounting standards the cross-border portfolio and direct investment my be distorted, the cross-border monitoring of management by shareholders obstructed, and the cross-border contracting inhibited and the cost of these activities may be needlessly inflated by complex translation (Meeks and Swann, 2009).

Standardization is the process of developing and agreeing upon technical standards. The standard is a document that establishes uniform engineering or technical specifications, criteria, methods, processes, or practices. Some standards are mandatory while others are voluntary. Voluntary standards are available if one chooses to use them. Some are de facto standards meaning a norm or requirement which has an informal but dominant status. Some standards are de jure meaning formal legal requirements. Formal standards organizations such as the International Organization for Standardization or the American National Standards Institute are independent of the manufacturers of the goods for which they publish standards.

In social sciences, including economics, idea of standardization is close to the solution for a coordination problem, a situation in which all parties can realize mutual gains, but only by making mutually consistent decisions. Standardization implies the elimination of alternatives in accounting for economic transactions and other events. Harmonization refers to reduction of alternatives while retaining a high degree of flexibility in accounting practices. 
Harmonization allows different countries to have different standards as long as the standards do not conflict. For example, within the European Union harmonization program, if appropriate disclosures were made, companies were permitted to use different measurement methods: for valuing assets, German companies could use historical cost, while Dutch businesses can use replacement costs without violating the harmonization requirements.

Since in case such multinational companies like Daimler Chrysler owning more than 900 subsidiaries, operating on 5 continents in more than 60 countries, the published financial results according to international standards is 1.5 times of the one according to German accounting standards. If earning after taxation (EAT) - deducted actual tax burdens - according to US GAAP is taken as 100 percent, due to differences between national accounting standards, EAT would be 25\% more in UK, 3\% less in France, 23\% less in Germany and 34\% less in Japan too (Barth et al.,2007).

The first argument for the harmonization of accounting information systems is the existence of the multinational companies, who invest enormous efforts into the preparation of their financial reports in order to comply with the national standards. For these companies life would be much easier if the same rules would be applied to their subsidiaries all around the world. On the other hand this would be profitable for the investors as well, as they could compare the enterprises' results without difficulties, which would spare both money and other resources for them. This would also lead to the reduction of the information diversity between managers and investors. The information diversity is a costly and can be blamed for the decrease of the managers' bonus, the increase of the equity's cost and the inaccuracy of the economical and the financial forecasts.

\section{Previous related literature review}

International accounting literature provides evidence that accounting quality has economic consequences, such as costs of capital (Leuz and Verrecchia, 2000), efficiency of capital allocation (Bushman and Piotroski, 2006) and international capital mobility (Guenther and Young, 2002).

Prior researches (e.g. Meeks and Meeks, 2002) have raised substantial doubt regarding whether a global accounting standard would result in comparable accounting around the world. But differences in accounting practices across countries can result in similar economic transactions being recorded differently. This lack comparability complicates cross-border financial analysis and investment.

Epstein (2009) compared characteristics of accounting amounts for companies that adopted IFRS to a matched sample of companies that did not, and found that the former evidenced less earnings management, more timely loss recognition, and more value relevance of accounting amount than did the latter. They found, that IFRS adopters had a higher frequency of large negative net income and generally exhibited higher accounting quality in the post-adoption period than they did in the pre-adoption period. The results suggested an improvement in accounting quality associated with using IFRS.

Chatterjee (2006) assigned that first time mandatory adopters experience statistically significant increases in market liquidity and value after IFRS reporting becomes mandatory. The effects were found to range in magnitude from $3 \%$ to $6 \%$ for market liquidity and from $2 \%$ to $4 \%$ for company by market capitalization to the value of its assets by their replacement value.

Daske et al. (2007) also found that the capital market benefits were present only in countries with strict enforcement and in countries where the institutional environment provides strong incentives for transparent filings. In the order IFRS adoption countries, market liquidity and value remained largely unchanged in the year of the mandate. In addition, the effects of mandatory adoption were stronger in countries that had larger differences between national GAAP and IFRS, or without a pre-existing convergence strategy toward IFRS reporting.

The increased transparency promised by IFRS also could cause a similar increase in the efficiency of contracting between firms and lenders. In particular, timelier loss recognition in the financial statements triggers debt covenants violations more quickly after firms experience economic losses that decrease the value of outstanding debt (Ball and Lakshmann, 2006, Ball and Shivakumar, 2007).

Accounting theory argues that financial reporting reduces information asymmetry by disclosing relevant and timely information (e.g. Frankel and Li, 2004). Because there is considerable variation in accounting quality and economic efficiency across countries, international accounting systems provide an interesting setting to examine the economic consequences of financial reporting. The EU's movement to IFRS may provide new insights as firms from different legal and accounting systems adopt a single accounting standard at the same time. Improvement in the information environment following change to IFRS is contingent on at least two factors. First, improvement is based upon the premise that change to IFRS constitutes change to a General Accepted Accounting Principles (GAAP) that induces higher quality financial reporting. Second, the accounting standards are a complementary component of the 
country's overall institutional system and they are also determined by businesses' incentives for financial reporting (Ball et al., 2006).

La Porta (1998) provided the first investigation of the legal system's effect on a country's financial system. He found that common law countries have better accounting systems and better protection of investors than code law countries. Other factors associated with financial reporting quality include the tax system (Daske and Gebhardt, 2006), ownership structure (Burgstahler et al., 2006, Jermakovicz et al., 2007), the political system (Gwilliam et al., 2005), capital's structure and capital market development (Ali et al., 2000). Therefore, controlling for these institutional and firm-level factors becomes an important task in the empirical research design. As a result of the interdependence between accounting standards and the country's institutional setting and firms' incentives, the economic consequences of changing accounting systems may vary across countries. Few papers have examined how these factors affect the economic consequences of changing accounting standards. For example, Pincus et al. (2007) measured that accrual anomaly is more prevalent in common law countries. Maskus et al. (2005) explored that accounting quality is associated with tax reporting incentives. Exploration of the interaction between these factors and the accounting standards can provide insights into differences in the economic consequences of changing accounting principles across countries.

\section{Methodology}

This study examines the impact of the adoption of international accounting standards on the management performance of businesses listed on the Budapest Stock Exchange in Hungary. The research work also seeks to identify the financial attributes of enterprises that national rules employed by the requirements of the Hungarian Financial Ministry.

Finally, the paper investigates whether international accounting standards reduces the level of earnings management and enhances the value relevance of CEO turnover.

My research is based on a qualitative comparative approach. In order to identify the results of my scientific research about the evaluation of the accounting standards in Hungary I have elaborated the following hypotheses:

H1: Businesses with lower labour productivity compared to their industry peers have greater incentives to adopt international accounting standards.

H2: The sensitivity of CEO turnover to accounting earnings increases after the adoption of international accounting standards.

H3: Standards user enterprises' employee layoffs are more response to accounting performance post-adoption.

The purpose of this study was the measuring the differences between the national rules and the international methods, the valuing and analyzing their effects on the business decisions. This survey contains information on how local, national accounting rules differ from IFRS on incorporating recognition, measurement, and disclosure rules.

To analyze business adoption decision my sample consists of Budapest Exchange Trade (BET) companies who compulsory adopted international financial reporting standards from 2005. My final sample comprises 65 IFRS adopting and 260 local (Hungarian) accounting rules user firms. For the chosen of the national accounting rules user enterprises I introduced mathematic-statistic methods. An alternative approach it to create a matched sample of local rules businesses based on criteria such as year and industry. It is chosen to incorporate all local rules firms due to methodological concerns about the matched-pairs research design. Financial data are from published accounting statements in BET and Hungarian Business Information database. In my sample the businesses are classified into those following IFRS and those following national accounting rules. For the IFRS adopting enterprises the adoption year is treated as event year 0. To analyze enterprises' adoption decision, I required data on stock returns, accounting earnings, total assets, market capitalization, leverage, growth, foreign sales one year prior to event year 0 , and closely held shares for event year 0. Close_Held is measured in event year 0 .

The adoption decision models are expanded relying Nobes (2006) researches and test if the demand from internal performance evaluations is a factor in businesses decisions to adopt international accounting standards.

It is estimated in the following logistic regression model (1) after the prior literature (Wu and Zhang, 2009):

$$
\begin{aligned}
& \text { Prob }[\text { Adopt }=1]=\text { Logit }\left(a_{0}+a_{1} \text { Close_Held }+\underset{0}{a} \text { Labor_Prod }_{-1}+\underset{3}{a} \text { RET }_{-1}+a_{4} \text { ROA }_{-1}+\right. \\
& \left.+\mathrm{a}_{5} \text { Size }_{-1}+\underset{6}{\mathrm{a}} \text { Lev }_{.-1}+\underset{7}{\mathrm{a}_{7} \text { Growth }_{-1}+\underset{8}{\mathrm{a} \text { Foreign_Sales }}-1}\right) \text {. }
\end{aligned}
$$

Where:

Close Held: Percentage of closely held shares at the end of event year (event year of 2008 for the management turnover and employee layoffs analyses) 
Labour Prod: Labour productivity (sales per employee) minus the median labour productivity

RET: Annual raw stock return

ROA: Return on Assets, accounting earnings is defined as net income before extraordinary items.

Size: Natural logarithm of market capitalization

Lev: Leverage, defined as long-term debt divided by total assets

Growth: Sales growth, current year's sales change divided by prior year's sales

Foreign Sales: Foreign sales divided by total sales.

The dependent variable Adopt is equal to 1 for adopting firms and 0 otherwise. All the independent variables are measured around event year 0 . This model includes year and industry dummy variables.

I included lagged variables on businesses performance ( RET $_{-1}$ and ROA -1 ), firm size $\left(\operatorname{Size}_{-1}\right)$, leverage $\left(\operatorname{Lev}_{-1}\right)$ ), growth $\left(\right.$ Growth ${ }_{-1}$ ) on the right-hand side of the regression model and I expected the coefficients on firm size, leverage and growth to be positive. I also included foreign sales as a percentage of enterprise total sales (Foreign_Sales ${ }_{-1}$ ). I expected these variables to have positive signs.

The regression results are reported in Table 1. Table 1 reports the logistic reports to model business decisions to adopt IFRS. In Table 1 the coefficients estimates, standard errors, and the marginal effects are reported in columns (1) to (3), respectively. The Close_Held ${ }_{0}$ has a negative coefficient, -0.00445 , and significant at the 0.05 level..

The percentage of closely held shares can also vary with business' incentives to access the capital market as more closely held business may have lower demand for external capital. This is the reason why the research controls for various factors related to business financing needs in the regression model.

The coefficient on Labor_Prod -1 is -0.00005 negative as expected and significant as the 0.05 level. The marginal effect indicates that a one standard deviation increase in labour productivity reduces the likelihood of adoption by 1.08 percent. Regression has reasonable predictive power with a Pseudo $\mathrm{R}^{2}$ of 32 percentages.

It was expected that the coefficients on the percentage of closely held shares (Close_Held $)_{0}$ ) and labour productivity (industry-adjusted sales per employee, $\left(\right.$ Labor_Prod $\left._{-1}\right)$ variables to be negative, because prior researches suggested that these variables associated with disclosure incentives have predictive power for the adoption decision (e.g. Botsari and Meeks, 2008, Schleifer and Vishny, 2003). The control variables signed that larger businesses, those with higher leverage, with more substantial foreign sales are more likely to adopt international standards. I found that Close_Held are consistent with compensation contracting demands affecting business decisions to adopt international accounting standards.

The marginal effect suggest that a one standard deviation increase in the percentage of closely held shares decreases the adoption likelihood by 0,64 percent, or 5 percent of unconditional adoption probability of 20 percent (65/325). This supports a greater demand for more informative and conservative accounting earnings due to management performance evaluations at more widely held by businesses stimulating to adopt international accounting standards.

I analyzed CEO turnover-to-performance sensitivities separately for the adopting standards and the national rules user samples using model (2):

$$
\begin{aligned}
\text { Prob [CEO_Turnover } \left.\mathrm{t}_{\mathrm{t}}=1\right]=\operatorname{Logit}\left(\mathrm{a}_{0}+\right. & \mathrm{a}_{1} \mathrm{DROA}_{\mathrm{t}-1}+\mathrm{a}_{2} \text { DRET }_{\mathrm{t}-1}+\mathrm{a}_{3} \text { Post }_{0}+\mathrm{a}_{4} \text { Post*DROA }_{\mathrm{t}-1}+ \\
& \left.+\underset{5}{\mathrm{aPost}^{*} \text { DRET }_{t-1}+\sum \mathrm{b}_{j} \text { Control variable }}{ }_{j}\right) .
\end{aligned}
$$

Where:

CEO_Turnover: 1 if there is a CEO turnover in event year $t$; 0 otherwise.

DROA: 1 if ROA of event year $\mathrm{t}-1$ is negative and 0 otherwise.

DRET: 1 if annual stock return of event year $\mathrm{t}-1$ is less than $20 \%$ and 0 otherwise.

Post: 1 of a firm-year observation is post-event year 0 , and 0 for pre-event year 0 observations (event year 0 itself is removed).

The dependent variable, CEO_Turnover ${ }_{t}$, is an indicator equal to 1 there is a CEO turnover in year $t$ and 0 otherwise. Post is an indicator variable, equal to 1 if the firm-year is post-event year 0 , and 0 otherwise (event year 0 itself is removed from the analysis). The study includes the explanatory variables from the earlier adoption decision regression (except for ROA and RET) to control for business incentives to adopt international accounting standards and their potential impact on CEO turnover. These variables are measured around year $t$. The results for model (2) are reported in Table 2. 
I expected a positive coefficient on Post*DROA for the adopting sample and negative for local accounting rules businesses. t-1

The insignificant coefficient on Post*DRET $\mathrm{t}_{-1}$ is inconsistent with an overall increase in the performance sensitivities of CEO turnover at the adopting firms that might result from concurrent organizational changes other than accounting changes.

In my management turnover test the indicator variable $D R O A$ equal 1 and the stock return 17 percent (below 20 percent). But the accounting earnings are timelier, less managed, and more conservative after the adoption of international accounting standards. Also they are more effective tools for businesses internal performance evaluations and governance as I found in my research too.

The next model (3) is an analysis of layoff-to-performance sensitivities separately for the adopting standards and local rules user samples.

$$
\begin{aligned}
& \operatorname{Prob}\left[\text { Layoff }_{\mathrm{t}}=1\right]=\operatorname{Logit}\left(\mathrm{a}_{0}\right.+\mathrm{a}_{1} \mathrm{DROA}_{\mathrm{t}-1}+\mathrm{a}_{2} \text { DRET }_{\mathrm{t}-1}+\mathrm{a}_{3} \text { Post }+\mathrm{a}_{4} \text { Post*DROA }_{\mathrm{t}-1}+\mathrm{a}_{5} \text { Post } \text { DRET }_{\mathrm{t}-1}+ \\
&+\sum \mathrm{b}_{\mathrm{j}} \text { Control variable } \\
& \mathrm{j}
\end{aligned}
$$

The dependent variable, Layoff $_{t}$, is an indicator, equal to 1 if there is a reduction of a business employee headcount of more than 5 percent in year $t$, and 0 otherwise. The explanatory variables on the right-hand side are the same as those in model (2) on management turnover, except for the addition of several control variables. Since the change in employee headcount can reflect contemporaneous changes in a businesses overall scale of operations, the study includes sales growth (Growth), change in foreign sales ( $\Delta$ Foreign_Sales), and an indicator variable for fixed assets disposal (Fix_Disposal), for year $t$.

The results for model (3) are reported in Table 3.

\section{Conclusion}

My research paper investigates the effects of international accounting system on business decisions, management performance and economic environment. The results showed that businesses with lower labour productivity compared to their industry peers have greater incentives to adopt international accounting standards. As hypothesis 1 predicted that businesses face a better need for informative measures of enterprises performance to facilitate internal performance evaluation, therefore a higher probability of international standards.

Controlling for the effects of macro-economic conditions and employee layoffs by including the market return in Hungary it was pointed that the coefficients on market returns had been insignificant in the various regressions. Analyzing the changes in labour productivity at the adopting businesses the tests did not show a significant decreasing in the productivity over the last 5 years. It could be that businesses' labour productivity is persistently low, not necessarily deteriorating continuously, in the several years leading up to the adoption. Meanwhile, there is a significant increase in labour productivity over event years.

I measured earnings and stock performances with indicator variables of negative Return on Assets (ROA) and stock returns, respectively. The indicators with continuous measures of ROA and stock returns were replaced. The inferences on employee layoffs are unaffected. However, the results on turnover are sensitive to this change in variable specification. This suggests that the increase in the sensitivity of turnover to accounting performance post-adoption is primarily driven by heightened turnover sensitivity to accounting losses (hypothesis 2). Both the business earnings and stock returns affected management turnover. The prior studies suggested that variables associated with disclosure incentives have predictive power for the adoption decision and showed that both earnings and stock returns affect management turnover (see, for example, Easton, 2006).

Hypothesis 3 is certified in my tests that the employee layoff sensitivity to poor accounting performance increased after the adoption of international accounting standards. The adopting firms' employee layoffs are more response to accounting performance in the post-adoption period. With respect to the control variables, the study founded that businesses with higher labour productivity, that are larger, with greater contemporaneous and lagged sales growth, and less frequent layoffs. On the other hand, businesses with higher leverage and divestitures have more frequent employee layoffs. Continental European countries are known for their strong employment protection laws and powerful labour unions (Zeff, 2006). Companies with more substantial foreign sales are better likely to adopt international accounting standards.

\section{References}

Ali, A., Hwang, L .S. \& Trombley, M. .A. (2000). Accruals and Future Stock Returns: Tests of the Naïve Investor Hypothesis. Journal of Accounting, Auditing \& Finance, 15, $45-63$. 
Ball, R. \& Laksmann, S. (2006). Earnings quality in UK private firms. Journal of Accounting and Economics, 39, 83-128.

Ball, R., Robin, A. \& Sadka, G (2006). The effect of international institutional factors on properties of accounting earnings. Journal of Accounting and Economics, 29, 417-434.

Ball, R. \& Shivakumar, L. (2007). The effect of international institutional factors on properties of accounting earnings. Journal of Accounting and Economics, 29, 417-434.

Barth, E., Landsman, R. \& Lang,H. (2007). International Accounting Standards and Accounting Quality. Research Paper. Stanford University Graduate School of Business.

Botsari, A. \& Meeks, G. (2008). Do acquirers manage earnings prior to share for share bid? Journal of Business Finance and Accounting, 35, 633-670.

Burgstahler, D., Hail, L. \& Leuz, C. (2006). The importance of reporting incentives: earnings management in European private and public firms. International Business Review, 23, 48-69.

Bushmann, R. \& Piotroski, J. (2006). Financial reporting incentives for conservative accounting: the influence of legal and political institutions. Journal of International Accounting, 27, 148-161.

Chatterjee, R. (2006). Performance pricing and covenants in debt contracts in the UK. Judge Business School Working Paper. 07. University of Cambridge.

Daske, H. \& Gebhardt, G. (2006). International Financial Reporting Standards and Experts. Perceptions of Disclosure Quality. Abacus, 42, 34-41.

Daske, H., Hail, L., Leuz, C. \& Verdi, R. (2007). Adopting a Label: Heterogenity in the economic Consequences of IFRS Adoptions. Journal of Business Finance \& Accounting, 33(3)\&(4), 329-375.

Easton, P. (2006). Use of forecasts of earnings to estimate and compare cost of capital across regimes. Journal of Business Finance \& Accounting Research, 23/ 2, 49-71.

Epstein, B. J. (2009): The Economic Effects of IFRS Adoption. The CPA Journal, 03, 26-31.

Frankel, M. R. \& Li, X. (2004). Characteristics of a Firm's Information Environment and the Information Asymmetry between Insiders and Outsiders. Journal of International Business Studies, 37, 229-259.

Guenther, A., \& Young, P. (2002). Financial Reporting Environments at International Capital Mobility. Journal of Accounting Researches, 08, 41-57.

Gwilliam, D., Macve, R., \& Meeks. G. (2005). The costs and benefits of capital do legal institutions and securities regulation matter? Journal of Accounting Research, 44(3), 485-531.

Jermakovicz, K., Kinsey, P. \& Wulf, I. (2007). The Value Relevance of Accounting Income Reported by DAX-30, German Companies. Journal of International Financial Management \& Accounting, 18.(3), 611-641

La Porta, R. (1998). Law and Finance. The Journal of Political Economy, 106, 1113-1155.

Leuz, C. \& Verrecchia, R. E. (2000). The economic consequences of increased disclosure. Journal of Accounting Research, 38, 91-124.

Maskus, K. E., Otsuki, T. \& Wilson, J. S. (2005). An empirical framework for analyzing technical regulations and trade. In. S .Henson, J..S., Wilson (eds): The WTOÖ and Technical Barriers to Trade. Cheltenham, Edward Elger.

Meeks, G. \& Meeks, J. (2002). Towards a Cost-Benefit Analysis of Accounting Regulation. London. Centre of Business Performance.

Meeks, G. \& Swann, P. (2009). Accounting standards and the economics of standards. Accounting and Business Research, .39, 191-210.

Nobes. G. (2006). A Survey of National Accounting Rules Benchmarked Against International Accounting Standards. Ninth Edition. London.

Pincus, M., Rajgopal, S. \& Venkatachalam, M. (2007). The Accrual Anomaly: International Evidence. The Accounting Review, 6, 89-111.

Shleifer, A. \& Vishny, R. (2003). Stock market driven acquisitions. Journal of Financial Economics, 70, 295-314.

Whittington, G. (2008). Harmonization or discord? The critical role of IASB conceptual framework review. Journal of Accounting and Public Policy, 27, 495-502.

Wu, S. \& Zhang, P. (2009). International Accounting Standards and Internal Performance Evaluation. The Accounting Review, 37, 1283-1311.

Zeff, R. (2006). The Empirical Economics of Standards. DTI, Economics Paper, 12. London: Department of Trade and Industry. 
Table 1. Logistic analysis of accounting standards adoption decision

\begin{tabular}{|lrlr|}
\hline Analysis & Estimate & Standard Error & Marginal Effects* \\
\hline Close_Held $_{0}$ & -0.00445 & $0.0026^{* *}$ & $-0.64 \%$ \\
Labor_Prod $_{-1}$ & -0.00005 & $0.0003^{* *}$ & $-1.08 \%$ \\
RET $_{-1}$ & -0.1134 & 0.1447 & $-0.30 \%$ \\
ROA $_{-1}$ & -0.5609 & 0.7148 & $-0.31 \%$ \\
Size $_{-1}$ & 0.2659 & $0.0461^{* * *}$ & $4.21 \%$ \\
Lev $_{-1}$ & 1.3004 & $0.4882^{* * *}$ & $1.12 \%$ \\
Growth $_{-1}$ & -0.2883 & 0.2021 & $-0.50 \%$ \\
Foreign_Sales $_{-1}$ & 1.2085 & $0.2301^{* * *}$ & $3.08 \%$ \\
\hline
\end{tabular}

(Source: Author's own construction)

**,*** Indicate that a coefficient is significantly different from zero at the 10 percent, 5 percent, 1 percent levels, respectively (one-sided tests for coefficients with predictions and two-sided tests for those without a prediction).

* Marginal effects measure the changes in the predicted probability from a one standard deviation increase from the mean for a continuous variable and form 0 to 1 for an indicator variable with the other variables measured at the mean.

Table 2. CEO turnover-to-performance sensitivity analysis

\begin{tabular}{|l|l|l|l|l|}
\hline \multirow{2}{*}{ Analysis } & \multicolumn{2}{l|}{ Standards adopter enterprises } & \multicolumn{2}{l|}{ Local rules user enterprises } \\
\cline { 2 - 5 } & Estimate & Standard Error & Estimate & Standard Error \\
\hline DROA $_{\mathrm{t}-1}$ & -0.2611 & 0.2469 & 0.2249 & 0.2055 \\
\hline DRET $_{\mathrm{t}-1}$ & 0.0221 & 0.2449 & $0.3002^{* *}$ & 0.0522 \\
\hline Post $_{\mathrm{t}}$ & -0.0415 & 0.1456 & 0.0110 & 0.0928 \\
\hline Post $_{\mathrm{t}}$ DROA $_{\mathrm{t}-1}$ & $0.8062^{* * *}$ & 0.3092 & -0.0175 & 0.2473 \\
\hline Post $_{\mathrm{t}}$ DRET $_{\mathrm{t}-1}$ & 0.0810 & 0.1960 & -0.0708 & 0.1961 \\
\hline Close_Held $_{\mathrm{t}}$ & 0.0007 & 0.1965 & 0.0026 & 0.1935 \\
\hline Labour_Prod $_{\mathrm{t}-1}$ & -0.0001 & 0.0002 & 0.0001 & 0.0001 \\
\hline Size $_{\mathrm{t}-1}$ & $0.0857^{* *}$ & 0.0406 & 0.0391 & 0.0345 \\
\hline Lev $_{\mathrm{t}-1}$ & -0.5109 & 0.5521 & 0.0282 & 0.3062 \\
\hline Growth $_{\mathrm{t}-1}$ & -0.2152 & 0.4063 & $-0.4028^{*}$ & 0.2749 \\
\hline Foreign_Sales $_{\mathrm{t}-1}$ & -0.2949 & 0.2092 & -0.0234 & 0.1710 \\
\hline
\end{tabular}

(Source: Author's own construction)

***,***Indicate that a coefficient is significantly different from zero at the 10 percent, 5 percent, 1 percent levels, respectively (one-sided tests for coefficients with predictions and two-sided tests for those without a prediction).

Table 3. Employee Layoff-to-Performance Sensitivity Analysis

\begin{tabular}{|l|l|l|l|l|}
\hline \multirow{2}{*}{ Analysis } & \multicolumn{2}{|l|}{ Standards adopter enterprises } & \multicolumn{2}{l|}{ Local rules user enterprises } \\
\cline { 2 - 5 } & Estimate & Standard Error & Estimate & Standard Error \\
\hline DROA $_{\mathrm{t}-1}$ & $0.2805^{*}$ & 0.1838 & $0.5126^{* * *}$ & 0.0844 \\
\hline $\mathrm{DRET}_{\mathrm{t}-1}$ & $0.2016^{* *}$ & 0.1050 & $0.1885^{* *}$ & 0.0592 \\
\hline Post $_{\mathrm{t}}$ & 0.0269 & 0.1162 & 0.0386 & 0.0432 \\
\hline Post $_{\mathrm{t}}^{*} \mathrm{DROA}_{\mathrm{t}-1}$ & $0.5345^{* *}$ & 0.2628 & 0.0034 & 0.0973 \\
\hline Post $_{\mathrm{t}}{ }^{\mathrm{DRET}} \mathrm{t}_{\mathrm{t}-1}$ & 0.1968 & 0.1403 & 0.0783 & 0.0682 \\
\hline Close_Held $_{\mathrm{t}}$ & $0.0033^{*}$ & 0.1985 & 0.0009 & 0.0765 \\
\hline Labour_Prod $_{\mathrm{t}-1}$ & -0.0006 & 0.0004 & $-0.0001^{* *}$ & 0.0001 \\
\hline Size $_{\mathrm{t}-1}$ & -0.0177 & 0.0289 & $-0.0274^{* *}$ & 0.0131 \\
\hline Lev $_{\mathrm{t}-1}$ & 0.3978 & 0.3831 & $0.3193^{* *}$ & 0.1353 \\
\hline Growth $_{\mathrm{t}-1}$ & -0.1266 & 0.2115 & $-0.3034 * * *$ & 0.0863 \\
\hline Foreign_Sales & -0.0563 & 0.1546 & 0.0354 & 0.0630 \\
\hline$\Delta$ Foreign_Sales & -0.2631 & 0.6219 & -0.3361 & 0.2683 \\
\hline
\end{tabular}

(Source: Author's own construction)

*The estimation results

**,***Indicate that a coefficient is significantly different from zero at the 10 percent, 5 percent, 1 percent levels, respectively (one-sided tests for coefficients with predictions and two-sided tests for those without a prediction). 